\title{
Saudi Arabia Approaching 2030: The Shift from Quantitative to Qualitative Ambitions in Education, Enhancing Human Development
}

\author{
Annalisa Pavan ${ }^{1}$ \\ ${ }^{1}$ Department of Philosophy, Sociology, Education and Applied Psychology, University of Padova, Italy \\ Correspondence: Professor Annalisa Pavan, Dipartimento FISPPA, Università degli Studi di Padova, via B. \\ Pellegrino 28, 35137 Padova, Italy. Tel: 39-49-827-1709.
}

Received: April 7, 2017

Accepted: May 4, 2017

Online Published: May 26, 2017

doi:10.5430/irhe.v2n2p8

URL: https://doi.org/10.5430/irhe.v2n2p8

\begin{abstract}
This paper has 3 goals. Firstly, to explain how since its establishment in the 1920s, the modern Kingdom of Saudi Arabia has always strongly encouraged and supported scholarships for those citizens who wished to study abroad. Secondly, to explore how education and higher education are seen and supported in Saudi Vision 2030, the National Transformation Program (NTP) and the Saudi national budget 2017. New strategies and plans for progress in Saudi Arabia include education as a major tool for the human development of the Saudi nation. And thirdly, to address the following questions: what can the European Union learn from Saudi higher education policies? How do the Saudi Arabian Way to Knowledge Society and the Europe of Knowledge differ?
\end{abstract}

Keywords: King Abdullah scholarship program, national transformation program, Saudi Arabia, Saudi higher education, Saudi vision 2030

\section{Introduction}

This paper has 3 goals. Firstly, to explain how since its establishment in the 1920s, the modern Kingdom of Saudi Arabia has always strongly encouraged and supported scholarships for those citizens who wished to study abroad, contrary to the widespread perception that Saudi Arabian scholarship-oriented policies emerged only in the aftermath of $9 / 11$.

Secondly, to explore how education and higher education are seen and supported in Saudi Vision 2030, the National Transformation Program (NTP) and the Saudi national budget 2017. Saudi rulers express a strong determination to retain traditional culture, beliefs and values, but at the same time they are fully aware of the need to look ahead and open up to the globalized world. In their view, the human development of the Saudi nation is best pursued first and foremost through investments in education at all levels, a view confirmed by analysis of the abovementioned documents.

And thirdly, to address the following questions: what can the European Union learn from Saudi higher education policies? How do the Saudi Arabian Way to Knowledge Society and the Europe of Knowledge differ?

Given that the currently dominant media narratives in the West concerning Saudi Arabia - the most controversial of the Arab Gulf states, as reported by Western commentators — often fail to provide seriously informative knowledge about the Kingdom, this paper will draw on Saudi sources whenever possible, in the belief that they are best placed to provide an insight into the complex, unique and largely unknown world of Saudi Arabian culture.

\section{Saudi Arabian Scholarship-Oriented Policies: From the Beginnings to the Present}

Since the 1920s, even before the modern Kingdom of Saudi Arabia was established in 1932, Saudi rulers have devoted great efforts to the development of education as a pivotal tool for the progress of the nation. In particular, scholarship-oriented policies for those citizens who wished to study abroad at foreign universities were adopted under King Abdulaziz in 1927. In addition to existing reports (Pavan, 2013), this paper clarifies that, according to the Proceedings of the International Conference on the History of King Abdulaziz ibn Abdulrahman Al Saud, held 1985 in Riyadh, "three learned men", Abdulwahhab Ashi, Muhammad Sa'id Al Amudi and Muhammad Bayari, agreed that "the only means through which the country could achieve its aspirations should be based on a high standard of education and that could only be attained by sending scholars abroad". Subsequently, they submitted a written proposal to the King, who set up an ad-hoc committee to discuss the proposal. And, "in addition to the three initiators, 
the committee included Shaikh Hafiz Wahba, Salih Shatta and Shaikh Salih Nasif. The committee's several meetings were concluded by the designing of the system of scholarships, which was submitted to King Abdulaziz, who gave his orders to immediately start sending scholars abroad, and the first batch of them was to be sent to Egypt. In effect, the Advisory Council issued its decision no.33 (dated October 28, 1927)" (p.235). Eventually, thirteen students were sent to Egypt to specialize in teaching and juristic law, technical education (mechanics), agriculture and medicine (pp.235-236). A second and then a third batch were sent to Egypt respectively in 1936 and 1942 (p.236). Al Mousa (2010) specifies that while the 1927 decision already made provision to meet all the expenses incurred by the members of the first batch, on condition that the students would go back to Saudi Arabia after graduation and work in the field assigned by the government, at the time of the second educational mission to Egypt a regulating system for overseas scholarship affairs was created. Moreover, in 1936 the Preparatory School of Scholarships was established by royal order, "as an institute of secondary level, which would qualify its graduates to pursue specialized theoretical or scientific studies at one of the Arab universities...at a time when the urgent need for specialized university studies in medicine, agriculture and engineering began to be felt by the State" (Proceedings, p.229). In the years that followed, the number of students, destinations and research fields grew in quantity and quality.

Among others, Abd-el Wassie (1970) reported that in the decade 1959-1969 the list of destinations included US, Germany, UK, Italy, Austria, Switzerland, France, Holland, Iraq, Lebanon, Egypt, Iran and Syria, and Medicine and Engineering were the most popular specializations (p.17). Al-Farsy (1982), drawing on the Ministry of Education figures, specified that in 1975 there were 5,108 Saudi students pursuing university undergraduate and graduate education abroad across an impressive range of 129 disciplines, the most popular being Medicine, with 1,086 students (pp.158-159). The American University country study edited by Nyrop (1984) points out that in 1983 there were close to 70,000 students enrolled in higher education in the Kingdom, and another 12,000 studying abroad (p.124). However, less than ten years later, an updated version of the country study, this time edited by Chapin Metz (1993), found that "The expansion of the university system in Saudi Arabia has enabled the kingdom to limit financial support for study abroad. Such restrictions had long been the desire of some conservatives, who feared the negative influences on Saudi youth from studying abroad. Since the mid - to late 1980s, the number of Saudi students going abroad to study has dropped sharply. In the 1991-92 school year, only 5,000 students were reported studying abroad; there were slightly more than 4,000 the previous year, with half of those studying in the United States" (pp.102-103).

The King Abdullah Scholarship Programme (KASP) - the most impressive Saudi educational initiative of recent years, which was established in 2005 (Pavan, 2013), twice extended and now in its third stage under the new name Custodian of the Two Holy Mosques' Overseas Scholarship Program (Ministry of Education, 2017a) — is certainly in keeping with the "munificent" (Chapin Metz, 1993, p.101) support to higher education and scholarships provided by the Saudi government. However, it is regrettable that support provided by the government since the beginnings of the modern Kingdom is usually overshadowed or simply forgotten, or worse, completely ignored, while focusing rather on the reasons behind the establishment of KASP.

KASP is described as "a form of soft diplomacy on behalf of the Saudi government in response to strained relations with the US after the 9/11 attacks" (American Observer, 2011), "an educational agreement brokered between former U.S. president George Bush and Saudi King Abdullah in 2005" (Taylor and Albasri, 2014, p. 109). Hilal et al. (2015) suggest that "The King argued that the 'education' program was crucial for the Saudi-US long-term relationship" (p. 258), while Maatouk and Hausheer (2015) explain that "King Abdullah chose to address this problem [unfavourable opinions about Saudi Arabia in the US] head-on by sending Saudis out into the world to act as ambassadors for their country, religion, and values" (p.1). Arab News (March 17, 2016) stresses that "The scholarship program began with an agreement between former King Abdullah and former American President George W. Bush who both wanted to increase the number of Saudi students in the United States", and Mosaad (2016) reminds readers of the "help and support" provided by George W. Bush to King Abdullah at the creation of KASP - probably overrating the involvement of the Bush presidency: see the final words of the Joint Statement dated 25 April 2005 released after the meeting between the two leaders: "We must work to expand dialogue, understanding and interactions between our citizens. This will include programs designed to increase the number of young Saudi students to travel and study in the United States".

\section{Saudi Arabia Approaching 2030: Education, Economy, Human Development}

Saudi Arabia is the birthplace of Islam, the biggest oil exporter in the world, the Arab world's largest economy, and home to the first university in the Arabian Peninsula, the King Saud University, opened in 1957. According to the 
latest official statistics, $51 \%$ of the Saudi population is under the age of 25, and if Saudis in their mid-30s are included, the number is nearer 75\% (General Authority for Statistics, 2016).

In the 1930s the majority of the population living in the Kingdom was nomadic and the illiteracy rate around $90 \%$ (Al Abdulkareem, p.3). In 1980 the literacy rate was "just over 50\% and was steadily increasing" (Nyrop, 1985, p.126). According to UNESCO (2017), the literacy rate of Saudis between 15 and 64 years old stands at 91.84\%, and reaches $99.31 \%$ between 15 and 24 years old.

Today in Saudi Arabia there are 26 public universities (Ministry of Education, 2017b), 10 private universities (Ministry of Education, 2017c) and 41 private colleges (Ministry of Education, 2017d). Between 2005 and 2015 the number of universities grew by $86 \%$ (Ministry of Education, 2015).

On the occasion of the Global Knowledge Society Forum in December 2013 in Dhahran, Khalid Al Falih, former President and CEO of Saudi Aramco, now Minister of Energy, Industry and Mineral Resources and chairman of the Board of Directors of Saudi Aramco, having stated that "The currency of the new realm is knowledge", went on to say: "Our desire is to move to societies of well-educated citizens, using the products of their minds to make the world a better place and build a sustainable higher standard of living for themselves and their families".

Saudi Vision 2030, the ambitious roadmap launched in April 2016 to introduce the Saudi Government's long-term goals for economic diversification and social development, stresses the link between education and a competitive economy: "We will continue investing in education and training so that our young men and women are equipped for the jobs of the future. We want Saudi children, wherever they live, to enjoy higher quality, multi-faceted education...We will also redouble efforts to ensure that the outcomes of our education system are in line with market needs"(p.36). In particular, the government is committed to "closing the gap between the outputs of higher education and the requirements of the job market", along with "helping students make careful career decisions, while at the same time training them and facilitating their transition between different educational pathways" (p.40). As to scholarship-oriented policies, it is confirmed that "scholarship opportunities will be steered towards prestigious international universities and be awarded in the fields that serve our national priorities" (p.36). Interestingly, there is an apparent shift from the quantitative to the qualitative perspective in Saudi Arabia on the education front, which provides a true indicator of a country's real and effective development.

In June 2016 the National Transformation Program (NTP) was launched to help fulfil Saudi Vision 2030 and to identify the challenges faced by government bodies in the economic and development sectors. The program establishes strategic objectives based on the Vision, addresses its challenges through 2020, and presents interim indicators that measure performance (p.10). As concerning the Ministry of Education, the only items of interest connected with the topics touched on by this paper are its Strategic Objective $n^{\circ} 1$, namely to Provide education services for all student levels, together with the relevant Vision 2030 objectives: to "Establish positive values and build an independent personality for citizens" and "Provide citizens with knowledge and skills to meet the future needs of the labor market", and the Key Performance Indicator identified as the percentage of illiterate Saudi adults over 15 years of age: given a baseline of 5.32, the 2020 target is set at 2.5, against a regional benchmark of 2 , and an international benchmark of 1 (pp.60-61).

As reported by the National Budget document for the Fiscal Year 2017, published 22 December 2016, with total projected expenditure set at SAR890 billion [\$237.3 billion] (p.22), spending on the education sector accounts for $22.5 \%$ of total allocations. In fact, the Saudi government have allocated SAR200 billion [ $\$ 53.4$ billion] for public education, higher education and training. "The sector's budget covers new projects and the expansion of existing ones belonging to educational activities at all levels of education...including labs, infrastructure for universities, institutes and colleges, as well as training and renovation of existing facilities" (pp.24-25). It is emphasized that "Work continues to complete the renovation of girls' colleges across different universities, with a total cost of more than SAR5 billion [ $\$ 1.3$ billion]" (p.25). And with regard to scholarships, "The Custodian of the Two Holy Mosques" Scholarship Program will continue; total number of students sent abroad to study under the supervision of the Ministry of (Higher) Education has exceeded 207,000 students including their companions. The annual expenditures of this program will amount to SAR16.5 billion [ $\$ 4.4$ billion]" (p.25). A closer examination of the 9 key sectors covered by the budget shows that education comes first, followed by the military (SAR191 billion, $\$ 51$ billion).

The United Nations human development approach comprises 7 dimensions of human development: long and healthy life; knowledge; decent standard of living; participation in political and community life; environmental sustainability; human security and rights; gender equality (United Nations Development Program website, accessed March 30, 2017). 
The pivotal role accorded to education by the cited Saudi documents is entirely in keeping with this definition of human development, not least when considering that Saudi Vision 2030 establishes the overall aim of building a "vibrant society, a thriving economy and an ambitious nation" (p.11).

Saudi rulers confirm their staunch support of education, and higher education in particular, as the catalyst for generating change, progress and economic diversification, in accordance with religious values and heritage. And yet, notwithstanding the latest Human Development Report credits the Kingdom with good performance, ranking 38 in a list of 51 countries classified as having "very high human development" (Human Development Report 2016 Overview, p.22), much more needs to be achieved by Saudi Arabia if its human resources are to thrive and its young talents realize their potential.

\section{What the European Union May Learn from Saudi Investments in Education}

The content and methods of Saudi higher education policies have in the past been largely imported from certain Western countries. Bold steps have been taken, and great emphasis has been placed on innovation, growth and quality. However, it is generally agreed that much remains to be done, especially in terms of accountability. At the same time, it must be remembered that educational reforms need time to produce measurable outcomes: longer, for example, than economic reforms. Nevertheless, the present writer believes that the European Union could already take three lessons from Saudi higher education policies and their impact.

Lesson One. While mindful of the current economic crisis affecting Europe on one hand, and on the other, the good performance of the expanding Saudi economy, it may be useful to compare Saudi investments in education in 2017 with planned European Union allocations to education and development over the years 2014-2020.

At the beginning of 2014 the European Union launched two programmes, Horizon 2020 and Erasmus Plus. Horizon 2020 is the EU Framework Programme for Research and Innovation. Its main priorities are excellent science, competitiveness of European industries and societal challenges, and its initial budget for the next seven years (2014-2020) was $€ 77$ billion (European Parliament, 2015), \$83.8 billion. Erasmus Plus is the EU programme aimed at boosting skills and employability, and modernising education and training at all levels. Its budget for the same period (2014-2020) was set at $€ 14.7$ billion (European Commission, 2013), $\$ 16$ billion. So the European Union allocated a total amount of $\$ 99.8$ billion in order to support the development of the European knowledge society over seven years, $\$ 14.2$ billion per year. Saudi Arabia announced total expenditure on the education sector amounting to around $\$ 53.4$ billion for the year 2017. Self-evidently, the EU allocations for education and development for the period 2014-2020 bear no comparison with the Saudi allocations for education in 2017.

In June 2015, the launch of the European Fund for Strategic Investments (EFSI, essentially an economic stimulus package), further lowered the amount to $€ 74.8$ billion [\$81.4 billion] (European Parliament, 2015, p.6). In the 2017 EU budget approved 1 December 2016, these cuts were offset by a $7.9 \%$ increase in commitments and a $1.2 \%$ increase in payments in the overall funding of Horizon 2020, while Erasmus Plus benefited from a $16.2 \%$ increase in commitments and a 4.5\% increase in payments (European University Association, 2016, and European Council, 2016). It is possible that further cuts could be introduced in the 2018 budget. If investing in education can be regarded as a growth-friendly policy, especially in the medium term, the prospect for the sustainable growth of a European Knowledge Society remains worryingly at risk. Member States could well reconsider the balance between their funding for research, competitiveness and innovation and that for education and training, in the light of the proportions allocated by Saudi Arabia.

Lesson Two. Long-established scholarship-oriented policies clearly demonstrate the serious commitment of Saudi rulers to the education of younger generations. Despite being the cradle of Western civilization and culture, today Europe is witnessing underinvestment in human capital and, even worse, in the young. With expressions such as Europe of Knowledge and European Research Area paraded on the one hand, and cuts in allocations made on the other, it is plain to see how rhetoric has dominated the European educational landscape up to now. That neglect of the educational needs of coming generations could well receive the same attention as is being given by Saudi Arabia.

Lesson Three. Educational planning is not only a question of funding. Education is in essence a project aimed at the improvement of people and nations, and planning for tomorrow requires courage and ambition, as well as a certain amount of faith in the future. Moreover, whilst it is true that having the resources to support educational plans does not necessarily mean having the political will to invest these resources in education, it is equally true that lack of resources coupled with lack of political will must inevitably result in the failure of any serious educational policies. All the evidence thus far shows that Saudi Arabia has planned with foresight and fortitude, guaranteeing financial 
and political commitment. In short, by investing in education, Saudi Arabia is investing in its future. Can the European Union learn from that example?

Nowadays, Saudi Arabia's efforts are focused on the building of what may be called the Saudi Arabian way to knowledge society, a process characterized by sustained and sustainable political commitment to investment in education - higher education in particular - the preparation of several detailed plans for future developments, international scholarships for younger generations, attention to the international debate on higher education, research into international best practices in higher education and, finally, a strong determination to retain local traditional culture, but at the same time awareness of the need to open up to the globalized world (Pavan, 2013, p.32).

In conclusion, one might well ask which is likely to be accomplished first, if ever: the Europe of Knowledge or the Saudi Arabian Knowledge Society?

\section{Concluding Remarks}

This paper seeks to highlight the continual importance of the Saudi rulers' commitment to education. New strategies and plans for progress in Saudi Arabia include education as a major tool for the human development of the Saudi nation. However, education is not only a matter of building or improving infrastructures; more needs to be done in the Kingdom in order to build a research-conducive environment, to improve the level of Saudi participation in the international academic debate, and to provide better teacher training, to name just a few of several debated issues. In short, the time has come for Saudi Arabia to shift from quantity to quality in its approach to education.

There are indications that such a shift is already in progress, and research is needed on topics such as the differences between KASP and the Custodian of the Two Holy Mosques Scholarship Program, employment rates for KASP graduates, the reasoning behind the ban on foreign universities establishing campuses in the Kingdom, and the efforts to expand vocational training, among many others. In particular, further research is needed, ideally from Saudi scholars first and foremost, who could also draw on Saudi official sources in Arabic in order to expand the scope and improve the accuracy of the contents presented in this paper.

What the world very often sees as baby steps in Saudi Arabia are in fact giant steps for a country existing as a State only since 1932. And while the Kingdom struggles to balance its traditions and values with the challenge of globalization, its long-established scholarship-oriented policies place great trust on the young, on the basis that "Putting their shoulders to the wheels of progress is the only way that they will keep up with the rest of the world" (Prince Turki AlFaisal, 2016).

\section{References}

Abd-el Wassie, A. W. (1970). Education in Saudi Arabia. Houndmills Basingstoke, UK: MacMillan \& Co. Ltd.

Al Abdulkareem, S. (n.d.). Historical Project. Education development in Saudi Arabia. Retrieved July 5, 2014, from faculty.ksu.edu.sa/.../Education\%20Development\%20in\%20Saudi\%20Ar.

Al Farsy, F. (1982). Saudi Arabia. A case study in development. London-Boston: Kegan Paul International Ltd.

Al Mousa, A. A. (2010). Experience of Scholarships to Foreign Universities in Saudi Arabia: A Model for Investment in Human Resources \& Their Contribution to Development. In Bechir, L. (Ed), Arab Regional Conference on Higher Education (Cairo, May 31, June 1-2 2009). Towards an Arab Higher Education Space: International Challenges and Societal Responsibilities (pp.717-724). Beirut: UNESCO Regional Bureau for Education in the Arab States.

Alfaisal, HRH Prince Turki. (2016). A Saudi view of events in the Middle East. The Gazhi al Gosaibi memorial Lecture, Saudi British Society, London, November 28, 2016. Retrieved January 19, 2017, from http://www.saudibritishsociety.org.uk/main/prevlectures21.html

American Observer. (2011). Since 9/11, massive influx of Saudi students. American University, Washington D.C., online magazine. Retrieved March 21, 2017, from http://wp11.americanobserver.net/2011/09/857/

Arab News. (2016, March 17). Saudi students in US recall King Abdullah's push for education. By Rodolfo C. Estimo Jr. (p.4, printed edition).

Chapin Metz, H. (Ed). (1993). Saudi Arabia. A country study. Research completed December 1992 under the Country Studies/Area Handbook program sponsored by the Department of the Army.

European Commission. (2013). Factsheet: Horizon 2020 budget. Retrieved March 27, 2017, from http://ec.europa.eu/research/horizon2020/pdf/press/fact_sheet_on_horizon2020_budget.pdf 
European Council. (2016). EU budget 2017 approved. Retrieved March 27, 2017, from http://ec.europa.eu/budget/news/article_en.cfm?id=201612011726

European Parliament. (2015). Horizon 2020 budget and implementation. A guide to the structure of the programme. European Parliamentary Research Service. Author: Vincent Reillon. November 2015- PE 571.312

European University Association. (2016). Draft EU Budget 2017: €10.3 billion for Horizon 2020, €2 billion for Erasmus+. $\quad$ Retrieved April $\quad 7, \quad$ 2017, from www.eua.be/activities-services/news/newsitem/2016/07/07/draft-eu-budget-2017-10.3-billion-for-horizon-2020 -2-billion-for-erasmus

General Authority for Statistics, Kingdom of Saudi Arabia. (2016). Demography Survey 2016.

Hilal, K. T., Scott, S. R, \& Maadad, N. (2015). The Political, Socio-economic and Sociocultural Impacts of the King Abdullah Scholarship Program (KASP) on Saudi Arabia. International Journal of Higher Education, 4(1), 254-267. http://dx.doi.org/10.5430/ijhe.v4n1p254

Kingdom of Saudi Arabia. (2017). National Transformation Program 2020. Retrieved January 2, 2017, from vision2030.gov.sa/en/ntp

Kingdom of Saudi Arabia. (2017). Saudi Vision 2030. Retrieved January 2, 2017, from vision2030.gov.sa/en

Maatouk, O., \& Hasheer, S. (2015). Educating Saudi and the World. King Abdullah Scholarship Program, Ministry of Education. Center for Innovative Government. Riyadh.

Ministry of Education, Kingdom of Saudi Arabia. (2015). Dr Al Sabti: Budget reflects leadership valuation of HE crucial role at building capital and knowledge society. Retrieved January 11, 2015, from http://www.mohe.gov.sa/en/news/Pages/29-12-2014.aspx

Ministry of Education, Kingdom of Saudi Arabia. (2017a). The Custodian Of the Two Holy Mosques' Overseas Scholarship Program, Phase III 1436-1440: "Your Job First and then Your Scholarship" Program. Retrieved March 21, 2017, from https://www.moe.gov.sa/en/HigherEducation/ExternalEducation/Pages/TheCustodianofTheTwoHolyMosquesO verseasScholarshipProgram.aspx

Ministry of Education, Kingdom of Saudi Arabia. (2017b). State Universities. Retrieved March 21, 2017, from https://www.moe.gov.sa/en/HigherEducation/governmenthighereducation/StateUniversities/Pages/default.aspx

Ministry of Education, Kingdom of Saudi Arabia. (2017c). Private Higher Education Universities. Retrieved March 21 , 2017, from https://www.moe.gov.sa/en/HigherEducation/PrivateHigherEducation/Pages/PrivateHigherEducationUniversitie s.aspx

Ministry of Education, Kingdom of Saudi Arabia. (2017d). Private Higher Education Colleges. Retrieved March 21, 2017 , from https://www.moe.gov.sa/en/HigherEducation/PrivateHigherEducation/Pages/PrivateHigherEducationColleges.a spx

Ministry of Finance, Kingdom of Saudi Arabia. (2017). 2017 Budget. Public Statement Copy. Retrieved January 2, 2017, from https://www.mof.gov.sa/en/budget2017/Pages/default.aspx

Ministry of Higher Education, Kingdom of Saudi Arabia. (1985). Selected Papers from the International Conference on the History of King Abdulaziz ibn Abdulrahman Al Saud. Al Imam Muhammad ibn Saud Islamic University, Riyadh, December 1-5, 1985. Translation by Mohamad S. Al Muharib. Published and supervised by the General Dept. of Culture and Publication.

Mosaad, K. (2016). How Will Saudi Arabia Revamp its Education System? Retrieved March 21, 2017, from https://www.fairobserver.com/region/middle_east_north_africa/will-saudi-arabia-revamp-education-system-110 $82 /$

Nyrop, R. F. (Ed). (1985). Saudi Arabia. A country study. American University, Foreign Area Studies. Research completed March 1984 under the Country Studies/Area Handbook program sponsored by the Department of the Army.

Pavan, A. (2013). A New Perspective on the Quest for Education: the Saudi Arabian Way to Knowledge Society. Higher Education Studies, 3(6), 25-34. http://dx.doi.org/10.5539/hes.v3n6p25 
Taylor, C., \& Albasri, W. (2014). The Impact of Saudi Arabia King Abdullah's Scholarship Program in the U.S. Open Journal of Social Sciences, (2), 109-118. http://dx.doi.org/10.4236/jss.2014.210013

UNESCO Institute for Statistics. (2017). Saudi Arabia. Education and Literacy. Retrieved March 27, 2017, from uis.unesco.org/country/SA

United Nations Development Program. (2016). Human Development Report 2016. Overview. Human Development for Everyone. $\quad$ Retrieved March 30, 2017, from http://hdr.undp.org/sites/default/files/HDR2016_EN_Overview_Web.pdf

United Nations Development Program. (2017). What is Human Development? Retrieved March 30, 2017, from http://hdr.undp.org/en/content/what-human-development

US Department of State. (2005). Joint Statement by President Bush and Saudi Crown Prince Abdullah. Retrieved March 21, 2017, from https://2001-2009.state.gov/p/nea/rls/rm/45327.htm 